\title{
CONCEPT OF RESOURCE CAPITAL IN COMPANIES
}

\author{
Marlena Grabowska, marlena@zim.pcz.pl \\ Czestochowa University of Technology, Poland \\ Faculty of Management
}

\begin{abstract}
Resource capital might be defined as a remaining, after exclusion of share capital, value of the equity being mainly a result of the company's operation and also a result of the formulated and implemented strategies of forming a capital structure within a particular entity. Therefore a resource capital is an equivalent of fixed and current assets of the company's owners, but not financed through share capital. A level of a positive or negative impact of resource capital on the value of equity depends on the value of each component of resource capital. Influence of net financial loss on value of equity is also remarkable.
\end{abstract}

The concept of resource capital can be derived from the term 'resource' (resources), commonly identified as a particular amount of property amassed as inventory or a reserve to be used in the future. ${ }^{1}$ This definition is attributed to both material and non-material items. The term is mainly used for natural resources, information, or energy. It is commonly used to determine, in the context of energy, financial, cash, know-how, fiscal, raw-material and language resources as well as in relation to experience, power, knowledge, foods and words. Among usual phraseological collocations, where a pivot point is a word 'resource' an expression pointing to 'own resources' might be highlighted, ${ }^{2}$ contrary to 'outside resources', which is not commonly used collocation.

In consideration of lexical meaning of the term 'resource', it must be assigned some positive features identified with the phenomena which are commonly approved. It should be also highlighted that a resource, being synonymous with inventory and reserves, relates to a wider category of meanings. Amassing and owning the resources is not only a reflection of activities associated with an attitude of being careful and having foresight but also a symptom and a sign of stability and somehow of wealth, prosperity and clear future.

Thus a resource might be treated as an amassed source of a particular property. Such an approach to the concept of resources leads, in consequence, to analogy of this term with equity in companies. It is also remarkable that both operational and strategic activity of a business entity is connected with using a variety of resources. It is necessary, in the course of company's operation, to own not only capital resources. It is also essential for managers and employees to own appropriate resources of knowledge and experience as well as cash or material resources which ensure continuity and cycle regularity of production or sales.

R. Borowiecki, J. Czaja and A. Jaki argue that a company means resources which accept a material or non-material, property, personnel or financial form amassed in right proportions and reasonably used in order to create and sell goods and services and to bring their owners measurable financial benefits. ${ }^{3}$ R. Finney, N. Campbell and M. Powell highlight that resources

\footnotetext{
${ }^{1}$ Słownik języka polskiego, red. M. Szymczak, PWN, Warszawa 1981, t. 3, s. 960.

${ }^{2}$ S. Skorupka, Stownik frazeologiczny języka polskiego, Wiedza Powszechna, Warszawa 1989, s. 779.

${ }^{3}$ R. Borowiecki, J. Czaja, A. Jaki, Strategia gospodarowania kapitałem w przedsiębiorstwie, TNOiK, Warszawa Kraków 1997, s.12.
} 
mean specific, for a particular business, components of property and competence controlled and used by the companies to develop and implement their strategies. ${ }^{4}$ 'Resource' strategy is also emphasized by J. Czupiał and M. Karaś. ${ }^{5}$ According to this theory, a company is a set of resources and abilities which determine effectiveness and efficiency of the entity in terms of execution of its goals. Company's operation is more efficient if the company owns more appropriate resources and knowledge within its strategy.

The literature survey indicates identification of the concept of company's capital with a concept of resource. ${ }^{6}$ In this light a capital as a resource is one of the productivity factors used during production and exchange. ${ }^{7} \mathrm{H}$. Walica indicates that capital resources in companies impact on both current operation of a company and the possibility to finance restructuring and development initiatives, and they usually determine a company's value and the benefits to the owners. ${ }^{8}$

Similar approach adopted B. Woźniak - Sobczak who argued that capital resources determine existence of a business and they essentially influence its condition, continuity and development. ${ }^{9}$ The abovementioned meaning relates to the capital in total as an economic resource in a company necessary to finance property of the unit. ${ }^{10}$ Resource capital, however, is a narrower concept associated with a part of company's equity.

R. Borowiecki identifies resource capital with reserve (supplementary) capital while emphasizing that it is created by a company from the profit and becomes a reflection of its selffinancing. ${ }^{11}$ Thus this capital should be treated as a part of equity separated from the share capital. This definition might be attributed a narrower approach to a resource capital which suggests that such a capital assumes only positive values.

H. Towarnicka presents similar division of equity. The author highlights in own sources of financing of a particular entity, two fundamental components: share capital and reserve capital, emphasizing that the latter might be defined as a resource or reserve capital. ${ }^{12}$ D. Kania and E. Dreliszek also associate level of resource capital with reserve capital in a company and claim that $i t$ increases the net value of the assets i.e. contribution of share capital to financing of property resources. $^{13}$

J. Duraj, M. Gmytrasiewicz, A. Kramańska and I. Olchowicz also treat resource capital as a part of the equity. However, their approach to resource capital is more complex. This capital is composed of three fundamental components: supplementary capital, reserve capital (encompassing revaluation reserve and other reserve funds) and self-financing capital. ${ }^{14}$ The latter is created from undivided financial result from previous years and financial net result of the financial year. The above-mentioned definition of resource capital, relating to a wider meaning of this economic category also suggests that this capital might accept, in particular cases, not only positive but also

${ }^{4}$ R. Finney, N. Campbell, M. Powell, Strategies and resources: Pathways to success?, Journal of Business Research 58 (2005) 1721-1729.

5 Podstawy nauki o przedsiębiorstwie, Praca zbior. pod red. J. Lichtarskiego, Wyd. AE we Wrocławiu, Wrocław 2001, s. 36.

${ }^{6}$ A. Duliniec, Struktura i koszt kapitału w przedsiębiorstwie, Wydawnictwo Naukowe PWN, Warszawa 2001, s. 13; R. Borowiecki, Zarzadzanie kapitałem trwałym w przedsiębiorstwie, Wyd. SECESJA, Kraków 1993, s. 9;

${ }^{7}$ B. Klimczak, Mikroekonomia, Wyd. AE im. Oskara Langego we Wrocławiu, Wrocław 1995, s. 27 ; E. Dichtl, O. Issing, Vahlens Großes Wirtschaftslexikon, Verlag C.H. Beck München 1993, s. 1084.

${ }^{8}$ H. Walica, Zarzadzanie kapitałem w przedsiębiorstwie, Wydawnictwo TRIADA, Dąbrowa Górnicza 1999, s. 13.

9 B. Woźniak - Sobczak, Wykorzystanie funkcji kapitału $w$ formułowaniu strategii rozwoju przedsiębiorstwa [w:] Przedsiębiorstwo na rynku kapitałowym, praca zbiorowa pod red. J. Duraja, OMEGA - PRAKSIS, Łódź 1998, s. 98.

${ }^{10}$ M. Gmytrasiewicz, Rezerwy w księgach rachunkowych, Difin, Warszawa 2002, s. 7.

${ }^{11}$ R. Borowiecki, Zarzqdzanie kapitatem trwatym w przedsiębiorstwie, op. cit., s. 28.

${ }^{12}$ Podstawy nauki o przedsiębiorstwie, Praca zbior. pod red. J. Lichtarskiego, op. cit., s. 102.

${ }^{13}$ D. Kania, E. Dreliszak, Zestawienie zmian w kapitale własnym, Ośrodek Doradztwa i Doskonalenia Kadr sp. z o.o, Gdańsk 2003, s. 28.

${ }^{14}$ J. Duraj, Podstawy ekonomiki przedsiębiorstwa, PWE, Warszawa 2000, s. 183; M. Gmytrasiewicz, A. Karmańska, I. Olchowicz, Rachunkowość finansowa, część 1, Difin, Warszawa 1996, s. 457. 
negative values. Its positive or negative nature in this case might be determined by the value of financial net result for the financial year.

Thus two fundamental components should be highlighted in equity, i.e. share capital and resource capital. When the company starts its operation, share capital is equal to the value declared by its owner and high enough to set up the business. However, it is remarkable that, according to current law regulations, a minimal share capital is defined by the provisions of the Commercial Companies Code (Art. 308). ${ }^{15}$ A comprehensive view of the primarily invested capital is received through reduction of the declared value by called-up and not paid share capital (art. 36 of the Accounting Act). ${ }^{16}$ This value corresponds with initial capital contributed by the owners. The value of share capital might be changed as a result of the policy accepted for this value. According to the provisions of the Commercial Companies Code (Art. 430 - 458) the processes which lead to rise or decrease in the value of share capital in a particular company should be indicated.

Resource capital might be defined as a remaining, after exclusion of share capital, value of the equity being mainly a result of the company's operation and also a result of the formulated and implemented strategies of forming a capital structure within a particular entity. Therefore a resource capital is an equivalent of fixed and current assets of the company's owners, but not financed through share capital. A level of a positive or negative impact of resource capital on the value of equity depends on the value of each component of resource capital. Influence of net financial loss on value of equity is also remarkable.

In consideration of the abovementioned interpretation of the resource capital, its form can be broadened by so called 'hidden reserves' being a difference between a market value of a particular component of the assets or liabilities and the value of its valuation within the balance. ${ }^{17}$ Creation of hidden reserves follows as a result of valuation of the assets below its actual value and also as a result of presentation of costs or liabilities with excessive values. ${ }^{18}$ This discrepancy undoubtedly impacts on the rise in real capital at company's disposal. Hidden reserves are generated as a result of a purposefully led and legally accepted balance policy.

Moreover, M. Gmytrasiewicz, A. Karmańska and I. Olchowicz argue that this type of reserves is a tool for 'principle of prudence' for valuation of the financial result and company's property. Its consequence is a conscious creation of worse view of a particular entity than the view of real status of its property and income. This procedure might be claimed to be a sign of being careful, which results from managers' efforts to improve comfort of business management. ${ }^{19}$ Users of accounting information are sure that the property and financial standing of a company might be actually better, but never worse, than the one described in the financial report. ${ }^{20}$ Value of hidden reserves does not determine a balance level of equity and therefore it is not present in financial reports.

Effect of financing by hidden reserves appears at the moment of their release, when a book value for a particular element of assets or liabilities differs from the value of a particular economic event (its market value). Hidden financing, which is not directly reflected in the balance, does not

\footnotetext{
${ }^{15}$ Ustawa z dn. 15 września 2000 r. Kodeks spółek handlowych, Dz. U. z 2000 r. Nr 94, poz. 1037.

${ }^{16}$ Ustawa z dn. 29 września 1994 r. o rachunkowości. Tekst ujednolicony 17 czerwca 2002r., Dz.U. z 2002 r. nr 76 , poz. 694.

${ }^{17}$ H.D. Möser, Finanz- und Investitionswirtschaft in der Unternehmung, Verlag Moderne Industrie, Landsberg am Lech 1993, s. 131.

${ }^{18}$ H. D. Torspecken, Finansowanie przedsiębiorstw $w$ warunkach gospodarki rynkowej, Wyd. Zachodniopomorskiej Szkoły Businessu przy Uniwersytecie Szczecińskim, Szczecin 1993, s. 55.

${ }^{19}$ M. Gmytrasiewicz, A. Karmańska, I. Olchowicz, Rachunkowość finansowa, część 1, op. cit., s. 420.

${ }^{20}$ M. Gmytrasiewicz, A. Karmańska, Rachunkowość finansowa, Difin, Warszawa 2004, s. 25.
} 
influence the increase in balance value of equity. This means that its value can not be determined without additional information. ${ }^{21}$

Abovementioned considerations concerning three-stage interpretation of the resource capital are presented in Fig. 1.

Figure 1

Three-stage approach to resource capital

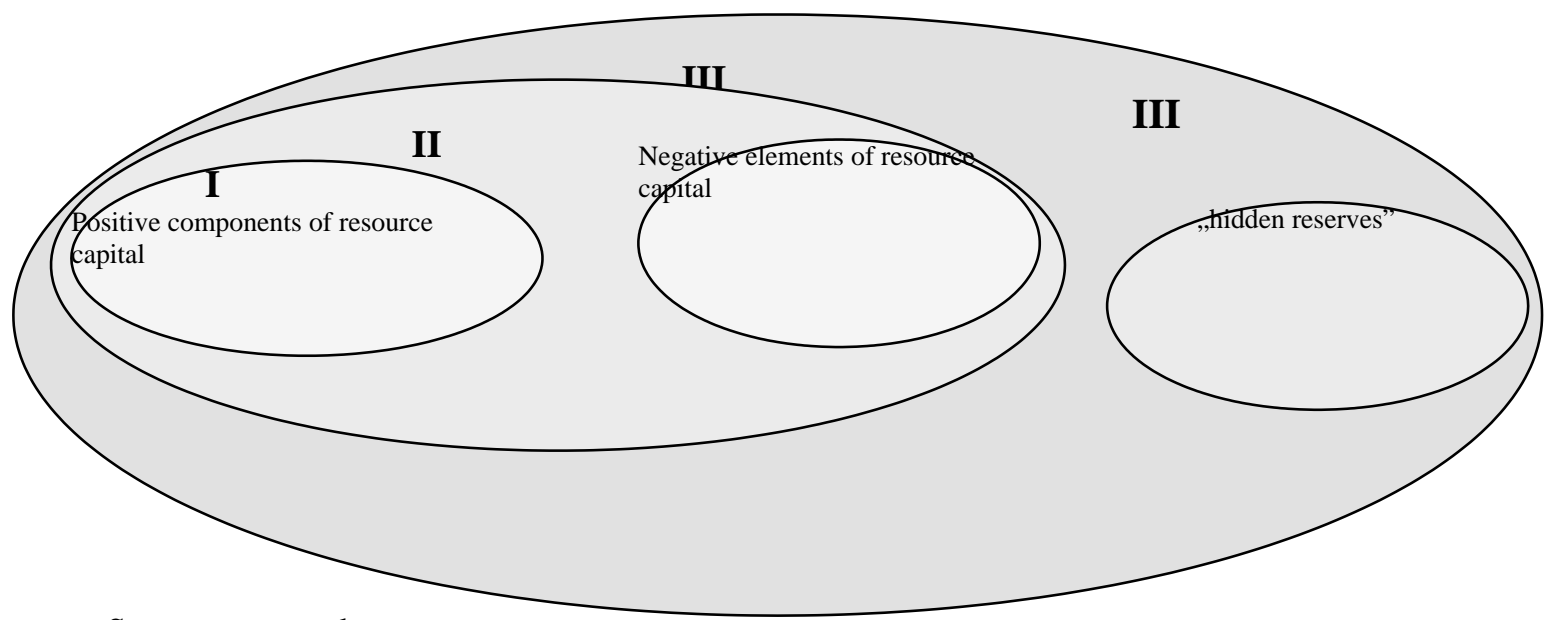

Source: own study

First stage shows a narrower approach to resource capital indicating that it assumes only positive values. Moreover, it can be proved that this value is a reflection of the positive equity separated from share capital and the reflection of the increase in the value of own sources of financing company's property.

Second stage indicates resource capital as a difference between a balance value of the equity and the value of share capital. This difference can accept both positive and negative values. In this case a nature of resource capital depends both on the policy accepted for formation of capital structure in a company and on the results of its operation, which respectively impacts on the rise or decrease in the described economic value. Due to this fact there are negative and positive values of the resource capital.

Third, and most extended, approach to resource capital indicates that it also contains the value of hidden reserves. However, it is remarkable that their scope, apart from the current regulations on valuation of assets and liabilities, is influenced by the specific financial policy executed within a company. Its consequence is a lack of possibility to find, within the financial report, a value of hidden reserves and objective valuation of its level.

These considerations enable to argue that the concept of resource capital is integrally connected with classification of company's capital, whose execution is based on a property category. The resource capital is a part of equity presented within financial report of a particular entity which is not a share capital. This definition corresponds to a second from the described approaches to resource capital.

Resource capital is a reflection of changes in value of equity during company's operation. Thus, this capital is a reflection of a difference between the company's property belonging to the owners and the value of share capital. Considering the abovementioned, the processes forming level of resource capital should be highlighted. These processes - in a general meaning - might be

21 H. Pernsteiner, Das Eigenkapital der Unternehmen, Abgrenzung und Umfang, Industrieverlag Peter Linde Ges.m.b.H., Wiedeń 1989, s. 38. 
defined as a resource capital management understood as acquisition, amassing and using of this source of financing according to current legal regulations and formulated and executed strategies of capital structure formation in a particular entity.

In a broader sense, the process of resource capital management might be related to the mechanism of management of financial resources being at company's disposal. R. Borowiecki, J. Czaja and A. Jaki prove that the process of capital management in a company is also connected with making autonomous decisions which lead to proper execution of goals in a particular entity. Synthetic view of a management process might be reduced to the form of chain: production distribution - exchange - consumption. Moreover, these authors claim that the transformation of the property, including capital property, leading to exchange of one set of items for another with increased market value, results in creation, by the entity, of new added values. ${ }^{22}$

J. Duraj argues that company's resource management should be understood as conditions, methods, processes, tools and mechanisms which impact on efficient acquisition, amassing and use of resources in order to satisfy social needs. This author also claims that the problems of such management within company must be solved with consideration of the rules and principles formulated from a point of view of realization of particular goals in management of a particular entity. ${ }^{23}$

H. Walica also associates the term of resource capital management in companies with the capital management in general. The author argues that the essence of capital management encompasses mainly the processes which consist in acquisition of necessary value of financial sources and then in reasonable, efficient and effective use which leads to multiplying the involved value of capital. Such an expression enables separation of the following components of the capital management process ${ }^{24}$ :

- reasonable and efficient use of the existing resources,

- making investment (development) decisions,

- (transformation) restructuring of the owned, and possible to be used, property and capital components.

E. A. Helfert also claims that the goal of reasonable management in companies is managing selected resources on a strategic level so that, in the course of time, to create an economic value which ensures not only covering but also a fair return on the incurred expenditures, not exceeding a level of risk accepted by the investors. ${ }^{25}$

Thus it should be emphasized that management of elements of equity should be performed through creation of long-term conditions for efficient and reasonable development of a company which results in actual improvement in economic standing of its owners. Thus resource capital management in companies should lead to improvement in the importance of share capital and, in consequence, of the equity in a particular company, resulting in creation of long-term conditions of its operation and efficient and sustainable growth.

The issues of resource capital management, although existing in the theory of management, is presented in a fragmentary way during considerations of company's financing. In economic references concerning issues of the capital one can find descriptions of the issues of capital reserves created by the entities, particularly the issues concerning supplementary capital and reserve capital. ${ }^{26}$ However, perceiving these economic categories within the criterion of resource

\footnotetext{
${ }^{22}$ R. Borowiecki, J. Czaja, A. Jaki, Strategia gospodarowania kapitałem w przedsiębiorstwie. Zagadnienia wybrane, op. cit., s. $11-12$.

${ }^{23}$ J. Duraj, Podstawy ekonomiki przedsiębiorstwa, op. cit., s. 29 - 30 i 38.

${ }^{24}$ H. Walica, Zarzqdzanie kapitałem $w$ przedsiębiorstwie, op. cit., s. 14.

${ }^{25}$ E. A. Helfert, Techniki analizy finansowej, PWE, Warszawa 2004, s. 24.

${ }^{26}$ Por. m.in.: H. Pernsteiner, Das Eigenkapital der Unternehmen, Abgrenzung und Umfang, op. cit.; L. Raettig, Finanzierung mit Eigenkapital, Hohes Eigenkapital = mehr Kreditwürdigkeit?, Fritz Knapp Verlag, Frankfurt am Main 1974; A. N. Duraj, Kształtowanie rezerw w przedsiębiorstwie, Wydawnictwo Uniwersytetu Łódzkiego, Łódź 2004,
} 
capital in companies is not a common approach in the subject literature. Thus, there is a need for indepth presentation of the issues of managing of resource capital due to the necessity of complex and systematic approach to equity management.

\section{Bibliography}

1. Borowiecki R., Czaja J., Jaki A., Strategia gospodarowania kapitałem $w$ przedsiębiorstwie, TNOiK, Warszawa - Kraków 1997

2. Borowiecki R., Zarzqdzanie kapitatem trwatym w przedsiębiorstwie, Wyd. SECESJA, Kraków 1993

3. Dichtl E., Issing O., Vahlens Großes Wirtschaftslexikon, Verlag C.H. Beck München 1993

4. Duliniec A, Struktura i koszt kapitału w przedsiębiorstwie, Wydawnictwo Naukowe PWN, Warszawa 2001

5. Duraj A.N., Kształtowanie rezerw w przedsiębiorstwie, Wydawnictwo Uniwersytetu Łódzkiego, Łódź 2004

6. Duraj J., Podstawy ekonomiki przedsiębiorstwa, PWE, Warszawa 2000

7. Finney R., Campbell N., Powell M., Strategies and resources: Pathways to success?, Journal of Business Research 58 (2005) 1721-1729.

8. Gmytrasiewicz M., Karmańska A., Olchowicz I, Rachunkowość finansowa, część 1, Difin, Warszawa 1996

9. Gmytrasiewicz M., Karmańska A., Rachunkowość finansowa, Difin, Warszawa 2004

10. Gmytrasiewicz M., Rezerwy w księgach rachunkowych, Difin, Warszawa 2002

11. Helfert E.A., Techniki analizy finansowej, PWE, Warszawa 2004

12. Kania D., Dreliszak E., Zestawienie zmian w kapitale własnym, Ośrodek Doradztwa i Doskonalenia Kadr sp. z o.o, Gdańsk 2003

13. Klimczok B., Mikroekonomia, Wyd. AE im. Oskara Langego we Wrocławiu, Wrocław 1995

14. Möser H.D., Finanz- und Investitionswirtschaft in der Unternehmung, Verlag Moderne Industrie, Landsberg am Lech 1993

15. Pernsteiner H., Das Eigenkapital der Unternehmen, Abgrenzung und Umfang, Industrieverlag Peter Linde Ges.m.b.H., Wiedeń 1989

16. Pernsteiner H., Das Eigenkapital der Unternehmen, Abgrenzung und Umfang,

17. Podstawy nauki o przedsiębiorstwie, Praca zbior. pod red. J. Lichtarskiego, Wyd. AE we Wrocławiu, Wrocław 2001

18. Raettig L., Finanzierung mit Eigenkapital, Hohes Eigenkapital = mehr Kreditwürdigkeit?, Fritz Knapp Verlag, Frankfurt am Main 1974 1989

19. Skorupka S., Słownik frazeologiczny języka polskiego, Wiedza Powszechna, Warszawa

20. Słownik języka polskiego, red. M. Szymczak, PWN, Warszawa 1981

21. Torspecken H.D., Finansowanie przedsiębiorstw $w$ warunkach gospodarki rynkowej, Wyd. Zachodniopomorskiej Szkoły Businessu przy Uniwersytecie Szczecińskim, Szczecin 1993

22. Ustawa z dn. 15 września 2000 r. Kodeks spółek handlowych, Dz. U. z 2000 r. Nr 94, poz. 1037.

23. Ustawa z dn. 29 września 1994 r. o rachunkowości. Tekst ujednolicony 17 czerwca 2002r., Dz.U. z 2002 r. nr 76, poz. 694.

24. Walica H., Zarzadzanie kapitałem $w$ przedsiębiorstwie, Wydawnictwo TRIADA, Dąbrowa Górnicza 1999

25. Woźniak - Sobczak B., Wykorzystanie funkcji kapitału w formułowaniu strategii rozwoju przedsiębiorstwa [w:] Przedsiębiorstwo na rynku kapitałowym, praca zbiorowa pod red. J. Duraja, OMEGA - PRAKSIS, Łódź 1998 